\title{
Health and Working Conditions of Women Nursing Students
}

\author{
Ana Paula de Lima1, Ana Paula Maklouf1, Thiago Lupernide Souza Dias, \\ Wendel Mombaque dos Santos' ${ }^{*}$, Catarina Rodrigues da Silva ${ }^{1}$ \\ ${ }^{1}$ Department of Nursing, Integrated College Teresa of Avila-FATEA, Pindamonhangaba, Brazil \\ ${ }^{2}$ Federal University of Santa Maria, Santa Maria, Brazil \\ Email: *wendelmombaque@hotmail.com
}

Received 24 March 2015; accepted 21 April 2015; published 27 April 2015

Copyright (C) 2015 by authors and OALib.

This work is licensed under the Creative Commons Attribution International License (CC BY). http://creativecommons.org/licenses/by/4.0/

(c) †) Open Access

\begin{abstract}
Objective: To identify health conditions of students in the undergraduate program in nursing working. Method: This is a descriptive study, conducted with the academic course of Bachelor of Nursing, with inclusion criteria work in the formal and informal market. Ethical aspects have been respected. Results: $\mathbf{5 7 . 7 0 \%}$ reported increase in body weight after beginning of the studies; $\mathbf{8 0 . 4 2 \%}$ did not practice physical activity; $55.67 \%$ did not consider their healthy eating; $37.11 \%$ lacked class/stage due to some health problems. The main complaints were sleep and tiredness $(78.35 \%)$, back pain $(38.14 \%)$ and attention deficit $(36.08 \%)$. The working hours of nursing students associated with several health problems of these, especially the physical and mental strain that can harm your studies, your personal life and professional performance.
\end{abstract}

\section{Keywords}

Women's Health, Students, Nursing, Nurse

Subject Areas: Nursing, Public Health

\section{Introduction}

Women's participation in the labor market has been increasing over the years, especially in developing countries, when they no longer performed only housework and also began to work formally to supplement the family income, characterizing the double shift [1].

To acquire more prominence in the labor market, women are seeking professional growth through undergraduate, i.e. higher education. The undergraduate nursing courses have theoretical and practical classes, so that the contaminant performance of these activities can bring physical and mental exhaustion [1]-[4].

\footnotetext{
"Corresponding author.
}

How to cite this paper: de Lima, A.P., Maklouf, A.P., Dias, T.L.S., dos Santos, W.M. and da Silva, C.R. (2015) Health and Working Conditions of Women Nursing Students. Open Access Library Journal, 2: e1451.

http://dx.doi.org/10.4236/oalib.1101451 
By taking academic activity and the work day, the woman shall have an understanding of the physical and mental exhaustion that may be exposed, so it is necessary to identify potential physical and psychological wear that affects the nursing students to develop strategies improvement in quality of life and thus promote health to working women seeking professional growth and personal fulfillment [5] [6]. Therefore, the objective of this research was to identify the health conditions of women students of nursing.

\section{Materials and Methods}

It consists of a cross-sectional survey of a descriptive nature, being conducted in four higher education institutions in the state of São Paulo/Brazil. This study was approved by the ethics committee.

The study population consists of women who hold undergraduate degree in Nursing and work. With the inclusion criteria were: (a) be a woman and be enrolled in undergraduate degree in nursing; (b) be placed on the market formal or informal work. And exclusion criteria: (a) students who were away from classes for sick leave or maternity leave of reason.

The sample base having a population of 3000 students, with a sampling error of $7 \%$ and reliability of $95 \%$, resulting in a minimum sample of 85 participants.

The data collection period was from March to April 2011, being held in the classroom, through a questionnaire consisting of open and closed questions to determine the health and work of the research participants.

Data were tabulated and analyzed using computerized process, using the SPSS 21.0 statistical package. The analysis included descriptive through the calculation of absolute and relative frequencies.

\section{Results}

Participated in the data collection 85 subjects had a mean age of $28.99 \pm 6.91$ years, $13.40 \%$ with wage income of less than $\$ 300,69.07$ with income between $\$ 300$ - \$900 dollars and 10.32\% with income above $\$ 900$ dollars and $69.07 \%$ were single.

To be addressed on body mass gain, $57.70 \%$ of participants had increased weight, with a mean of 24.88 body mass index (BMI). With regard to lifestyle, 55.67\% do not consider your healthy eating, $80.42 \%$ do not exercise, and $8.24 \%$ were smokers and $29.89 \%$ drank alcohol socially, with 6 average hours of sleep daily.

The health care be covered $26.80 \%$ were treatments, $8.24 \%$ used drugs and $37.11 \%$ had been absent from class due to some health reasons.

Regarding job characteristics $96.88 \%$ receives compensation, $63.92 \%$ have rest period, $70.10 \%$ are exposed to physical stress load, $82.47 \%$ have difficulty in work and study, $39.17 \%$ already missed work due to illness and the average weekly hours was 41 hours.

With regard to working hours, $63 \%$ worked at night and were exposed to biological hazards and physical risks. The principal complaints during the class period and work sleep and fatigue, swelling in the legs, back pain, mood changes and attention deficit, as shown in Table 1.

\section{Discussion}

The average age of students was 29 years, meeting with research showing that women have increasingly sought to financial independence, especially in the period between 25 and 30 years, and were not married and few had children [1] [7]. The focus in this period is aimed at professional life, later to found a family.

Searching for financial independence has influenced the composition of some families, which are now headed by women, accounting for family income or when they need care for their children without parental help [7]-[9].

There is a lack of healthy habits and the lack of physical activity increases the risk of cardiovascular disease, stress, cancer, diabetes and obesity [10]. The students should be made aware of the importance of practicing physical activity and nutrition, aiming to promote health.

The lack of physical activity and healthy habits is related to complaints of the musculoskeletal system caused by inadequate ergonomic and postural factors in the workplace. Women are more likely to have health problems due to occupational hazards [11] [12].

Exposure to occupational hazards demonstrated unfavorable conditions in the workplace, which can cause accidents and occupational diseases according to their job category such as long-term standing, bad posture, moving patients, among others who are gradually taking the working to illness [12] [13]. 
Table 1. Distribution of nursing students according to characteristics of the work.

\begin{tabular}{|c|c|c|}
\hline \multirow{2}{*}{ Characteristics } & \multicolumn{2}{|c|}{ Frequency } \\
\hline & $\mathbf{n}=\mathbf{9 8}$ & $\%$ \\
\hline \multicolumn{3}{|l|}{ Working period } \\
\hline Morning & 05 & 5.10 \\
\hline Afternoon & 31 & 31.64 \\
\hline Night & 62 & 63.26 \\
\hline \multicolumn{3}{|c|}{ Exposure to occupational risks } \\
\hline Biological & 57 & 58.81 \\
\hline Physical & 43 & 43.87 \\
\hline Chemicals & 30 & 30.61 \\
\hline Ergonomic & 38 & 38.77 \\
\hline \multicolumn{3}{|c|}{ Complaint/discomfort during the study/internship or work } \\
\hline Sleep & 76 & 80.61 \\
\hline Tiredness & 76 & 80.61 \\
\hline Swelling in the legs & 31 & 31.63 \\
\hline Backache & 37 & 37.75 \\
\hline Nausea & 11 & 11.22 \\
\hline Vomit & 01 & 01.02 \\
\hline Appetite changes & 21 & 21.42 \\
\hline Changes in behavior & 37 & 37.75 \\
\hline Dizziness & 23 & 23.46 \\
\hline Attention deficit & 35 & 35.71 \\
\hline
\end{tabular}

Exposure to environmental risks is because of the workers and students changes of the menstrual cycle, early menopause and problems during pregnancy and gynecological complaints regarding the device [11] [12].

The night worker who does not have break time can influence the metabolism, attention deficit and changes in blood pressure levels [14]. Because of this higher education institutions have developed courses in the afternoon.

It was noticed that the students are overloaded with responsibilities and work. It is the educational institutions and job that offer conditions to provide better quality of life for nursing students [11] [12].

The working hours of nursing students led to several health problems. It was demonstrated through sleep, fatigue and attention deficit that sometimes they did not attend to school or work due to health problems. It perceived controversy, because the students were seeking training to care for the health of the population, but not to take care of their own health. We have to educate these students self-care, so that the physical and mental strain does not harm their studies, personal life and professional performance [11]-[13].

The implications for the practice of nursing staff are to follow these workers who perform double shifts to make preventive guidelines and measures to minimize the health hazards of this, in order to maintain the intellectual and professional income.

\section{References}

[1] Madalozzo, R., Martins, S.R. and Shiratori, L. (2010) Participação no mercado de ticipação no mercado de trabalho e no trabalho doméstico: Homens e mulheres têm condições iguais? Revista Estudos Feministas, 18, 547-566. http://dx.doi.org/10.1590/S0104-026X2010000200015 
[2] de Oliveira, S.R. and Piccinini, V.C. (2011) Mercado de trabalho: Múltiplos (des) entendimentos. Revista de Administração Pública, 45, 1517-1538. http://dx.doi.org/10.1590/S0034-76122011000500012

[3] de Melo Costa, S., Durães, S.J.A. and de Abreu, M.H.N.G. (2010) Feminização do curso de odontologia da Universidade Estadual de Montes Claros. Ciênc Saúde Coletiva, 15.

[4] David, H. and Acioli, S. (2010) Mudanças na formação e no trabalho de enfermagem: Uma perspectiva da educação popular e de saúde. Revista Brasileira de Enfermagem, 63, 127-131. http://dx.doi.org/10.1590/S0034-71672010000100021

[5] Valente, G.S.C., Cortez, E.A., Assiz, M.M., Oliveira, J.M., Santos, P.F. and Feliciano, R.G. (2013) Occupational Risks and Diseases of Nursing University Lectures: Implications to the Worker Healthy. Revista de Pesquisa: Cuidado é Fundamental, 5, 3267-3275.

[6] Alves, E.F. (2012) Demographical and Occupational Characteristics of the Student-Worker of Nursing and the Risk of Accidents at Work. Trabalho \& Educação, 20, 47-59.

[7] Longo, L.A.B. (2013) Juventude e contracepção: Um estudo dos fatores que influenciam o comportamento contraceptivo das jovens brasileiras de 15 a 24 anos. Revista Brasileira de Estudos de População, 19, 229-247.

[8] Pinto, R.M.F., Micheletti, F.A.B.O., Bernardes, L.M., Fernandes, J.M.P.A., Monteiro, G.V., Silva, M.L.N., et al. (2011) Condição feminina de mulheres chefes de família em situação de vulnerabilidade social. [Feminine Condition of Women Heads of Family in Situation of Social Vulnerability.] Serviço Social \& Sociedade, 105, 167-179. http://dx.doi.org/10.1590/S0101-66282011000100010

[9] da Costa, D.I.P. (2013) As mulheres chefes de domicílios ea formação de famílias monoparentais: Brasil, século XIX. Revista Brasileira de População, 17, 47-66.

[10] Santana, M.S. and Chaves Maia, E.M. (2009) Atividade Física e Bem-Estar na Velhice. Revista de Salud Pública, 11, 225-236. http://dx.doi.org/10.1590/S0124-00642009000200007

[11] Oliveira, E.R.A., Garcia, Á.L., Gomes, M.J., Bittar, T.O. and Pereira, A.C. (2012) Gênero e qualidade de vida percebida: Estudo com professores da área de saúde. Ciênc Saúde Coletiva, 17, 741-747. http://dx.doi.org/10.1590/S1413-81232012000300021

[12] Grande, A.J., Silva, V., Manzatto, L., Rocha, T.B.X., Martins, G.C. and Vilela Junior, G.B. (2013) Comparação de intervenções de promoção à saúde do trabalhador: Ensaio clínico controlado randomizado por cluster. Revista Brasileira de Cineantropometria e Desempenho Humano, 15, 27-37. http://dx.doi.org/10.5007/1980-0037.2013v15n1p27

[13] Mininel, V.A., Felli, V.E.A., Silva, E.J., Torri, Z., Abreu, A.P. and Branco, M.T.A. (2013) Workloads, Strain Processes and Sickness Absenteeism in Nursing. Revista Latino-Americana de Enfermagem, 21, 1290-1297. http://dx.doi.org/10.1590/0104-1169.2992.2366

[14] Veiga, K.C.G., Fernandes, J.D. and Paiva, M.S. (2013) Análise fatorial de correspondência das representações sociais sobre o trabalho noturno da enfermeira. Revista Brasileira de Enfermagem, 66, 18-24. http://dx.doi.org/10.1590/S0034-71672013000100003 